\title{
Microfinance institutions in the development of financial markets
}

\section{Eva Terberger}

Professor

Department of Economics, University of Heidelberg, Germany eva.terberger@awi.uniheidelberg.de
For the last two decades, microfinance has ranked high on the list of policy instruments for fighting poverty. Supporting the creation of access to formal financial services for lowincome households holds out the promise of improving the living conditions of poor families and fostering economic development. Furthermore, it is claimed to be a very costeffective approach because some non-governmental organizations (NGOs) that have been upscaled into microbanks have shown that financial services can be offered to low-income households while covering costs and even earning a moderate profit. Recent studies, however, are sceptical about the high expectations raised by the microfinance approach, since profitable microfinance institutions (MFIs) are the exception rather than the rule. Institutional innovation is called for in order to reproduce these rare successes on a larger scale. This article aims to offer preliminary insights into the potential of two rather new institutional alternatives to upscaling: the creation of microfinance departments at existing for-profit banks (i.e., downscaling) and the founding of greenfield banks. 


\title{
Motivation: can proper institution- building make the microfinance promise come true?
}

\begin{abstract}
"About one billion people globally live in households with per capita incomes of under one dollar a day. The policymakers and practitioners who have been trying to improve the lives of that billion face an uphill battle... Amid the dispiriting news, excitement is building about a set of unusual financial institutions prospering in distant corners of the world-especially Bolivia, Bangladesh, and Indonesia. The hope is that much poverty can be alleviated - and that economic and social structures can be transformed fundamentally - by providing financial services to low-income households.

These institutions, united under the banner of microfinance, share a commitment to serving clients that have been excluded from the formal banking sector..." 1
\end{abstract}

The glimmer of hope raised by the "microfinance promise" could hardly be captured any more vividly than in this opening passage of Jonathan Morduch's lead article of the same title in the December 1999 issue of Journal of Economic Literature. The essay deserves to be considered a milestone in the literature on microfinance, for two reasons.

- Firstly, the topic of microfinance had for years received broad attention from development practitioners and politicians alike. However, up to the time of that publication, interest in the topic had been confined to a small community of scientists leading a rather closed-shop existence. Morduch's achievement was to introduce the topic to a broad range of economists in academia.

- Secondly, the paper explicitly states that despite the millions of dollars of donor aid that for more than two decades were devoted to and are still flowing into the building of microfinance institutions (MFIs) "the greatest promise of microfinance is so far unmet, and the boldest claims do not withstand close scrutiny" (Morduch, 1999, p. 1571).

What is the promise of microfinance all about? What hopes have so far been disappointed? The basic idea of microfinance is fairly simple: the development of the financial market through the creation of access to formal financial services for low-income households -and, more importantly, for small-scale entrepreneurs and microentrepreneurs- gives beneficiaries the opportunity to help themselves. They can escape poverty by stabilizing their consumption streams and by obtaining investment loans to improve their businesses, thereby raising household income, contributing to job creation and fostering the development of a vibrant sector of small enterprises as well as economic growth in general. Furthermore -and this seems to be the most attractive feature of the microfinance approach - fighting poverty by offering access to financial services holds out the promise of being relatively cost-effective. After an initial phase of subsidized institution-building, MFIs are supposed to reach financial sustainability. ${ }^{2}$ The promoters of the microfinance movement are convinced that financial services for the poor can be organized so as to cover costs, enabling MFIs to survive in the market without any further financial support and even to earn a moderate profit. If this could indeed be achieved, microfinance would create a "win-win solution" advantageous to poor clients and the owners of MFIs alike. With no need for further fuel in the form of continual subsidies, the commercial forces of the financial market could continue to fight poverty as if they were a perpetuum mobile.

${ }^{1}$ See Morduch, 1999, p. 1569.

${ }^{2}$ See Krahnen and Schmidt (1994). 
The evidence examined in Morduch's paper gives reason to be sceptical about how realistic feasible microfinance really is. Concerning the impact on poverty, very few empirical studies actually monitor the data of MFI customers for possible biases. ${ }^{3}$ Therefore, other than some illustrative case studies, empirical evidence of a positive impact of microfinance on clients' living conditions and job creation is scarce. Furthermore, there also seems to be good reason to question the claim that microfinance - after a limited period of subsidized institution-building — can develop into a zero-cost weapon against poverty. Although many MFIs can point to considerable successes in assessing the credit risk of microfinance clients once presumed to be "unbankable", "high repayment rates have seldom translated into profits as advertised" (Morduch, 1999, p. 1571). The dream of MFIs creating a "win-win solution" and of commercial banking becoming a driving force in fighting poverty seems to be highly unrealistic. Of the thousands of MFIs in the world, only a handful of flagship institutions are really meeting their dual mission of serving the target group of the poor and simultaneously being financially sustainable.

In the light of these sobering facts, Morduch concludes that one needs to be more realistic about the microfinance promise, although without giving it up altogether. The idea of offering self-help in the form of access to financial services is simply too attractive to be abandoned, not least because the history of microfinance has shown that considerable improvements can be made by learning from past mistakes. The first generation of microfinance projects, which came into being in the 1970s and relied on subsidized loans as a "gift" for the unbankable poor, had dismal results. ${ }^{4}$ Huge amounts of money were lost, because loans were seldom repaid. ${ }^{5}$ Furthermore, as subsidized loans have a broad appeal, the money often did not even reach members of the target group. ${ }^{6}$ The lessons learned from these failures resulted in a new approach to microfinance designed to prevent such loans from being misconstrued as gifts. Such financial "gifts", rather than helping to develop financial-market

\footnotetext{
${ }^{3}$ See Khandker, Samad and Khan (1998); Morduch (2000).

${ }^{4}$ See Vogel (1984).

5 "The most important element of credit subsidization was not the artificially low lending rate, but rather the fact that clever (and influential) borrowers had a good chance of avoiding repayment of their loans altogether". Krahnen and Schmidt (1994, p. 20).

${ }^{6}$ See Adams, Graham and Von Pischke (1984).
}

mechanisms, had disrupted them. This led to the creation of the so-called market-oriented approach to microfinance. Low-income households not served by formal banks were regarded as clients able to repay their loans if the MFI insisted on a repayment discipline. Furthermore, interest rates on microloans had to be at least as high as the market rate for larger loans in order to make them unattractive to unintended recipients. Henceforth, microfinance ceased to be regarded as a vehicle for the transfer of wealth to the poor, and instead came to be considered as an instrument for the development of financial markets.

This first wave of institutional innovation, focusing on credit technology and client-institution relations, has allowed today's MFIs to attain high repayment rates. These successes — which, at least for some shining examples among MFIs, translated into cost coverage, profits and formal registration as financial institutions (an achievement presumed impossible only a few years before)- were the root of the dream of the "win-win solution". Given that this dream has not yet come true on a large scale, the advice offered by Morduch and others $^{7}$ is to improve the institutional set-up of MFIs and "take another hard look at management structures and mechanism design in order to lower costs while maintaining outreach. Doing so will be far from simple, and it is hard to imagine substantial progress without a second major wave of innovation" (Morduch, 1999, p. 1609).

In fact, much innovation has taken place in this field during the last few years, in particular regarding the institutional set-up of MFIs and their ownership and governance structure. The vast majority of MFIs on which Morduch's assessment is based are still, or at least started off as, NGOs. The most successful of them may have changed their legal structure during the process of "upscaling" (i.e., while becoming formal banks specializing in microfinance), as did the flagship institutions of the microfinance movement in Bolivia, BancoSol and Caja Los Andes. ${ }^{8}$ Inspired by their successes and the dream of commercializing microloans, donors started to experiment with institutional alternatives to the upscaling of NGOs. Projects to establish microloan departments in existing institutions of the formal financial sector (i.e., to "downscale") were among the institutional innovations

\footnotetext{
${ }^{7}$ Such as Banerjee (2002) and Hulme and Mosley (1998).

${ }^{8}$ See Rhyne (2001).
} 
that were experimented with in the 1990s. In the latter part of the decade, donors took to another new approach. Instead of upscaling NGOs, they set up greenfield banks specialized in microfinance but possessing a banking licence from the very outset. These banks were founded as corporations, with donor institutions and private investors acting as the shareholders. Furthermore, an investment company specialized in equity holdings in MFIs assumed a leading role in founding these de novo banks. These institutional innovations sound much more like "real" financial business than does the long drawnout process of transforming an NGO originally meant to help the poor into a formal banking institution. Has the era of commercial microfinance begun, after all? Do these institutional innovations in building MFIs have the potential for making the microfinance promise come true on a bigger scale? These are the questions that the following sections of this article will address.

Section II classifies the institutional options for building MFIs into upscaling, downscaling and the founding of greenfield banks. This structure is intended to serve as a kind of theoretical basis for not only identifying the different institutional characteristics of these three approaches but also affording a preliminary glimpse of their potential advantages and drawbacks. Sections III and IV provide some empirical evidence on selected downscaling projects and on initiatives involving the creation of greenfield banks that may give an initial idea of their potential. The last section draws some preliminary conclusions.

\section{II}

\section{Downscaling a for-profit bank:}

\section{the opposite strategy to}

\section{upscaling an NGO}

Convincing an established commercial bank to hand out microloans on its own account, without government regulations requiring it to do so, used to be considered a rather hopeless endeavour. After all, it was these banks' lack of interest in serving low-income customers that gave rise to the idea of microfinance as a tool of economic development. Even experts who were well informed about the successes of the market-oriented approach to microfinance in the 1980s and the early 1990s were rather sceptical about downscaling projects. Hulme and Mosely, who published the results of their research on institution-building in microfinance in 1996, concluded: "The most significant observation must be that non-profit institutions (including publicsector and non-governmental organizations) appear to have a comparative advantage over for-profit institutions in providing formal financial sector services to poor people" (Hulme and Mosley, 1996, p. 157). They base their assertion on three central arguments:

- The first is of an empirical nature: hardly any of the institutions examined was a purely for-profit company: "the only private company in our study that was providing such services, and that had reached a relative state of maturity, was BancoSol.
This had its origins in PRODEM, a nongovernmental organisation" (Hulme and Mosley, 1996, p. 157).

- The other two arguments are of a more theoretical nature and refer to the institutions' governance structure: firstly, "private companies are simply not prepared to provide the venture capital for experimental services to low-income borrowers (and savers)... The second reason relates to the erroneous assumption that features of privatesector management that are essential to the effective provision of financial services (costing and pricing services, recovering costs, promoting a performance orientation in staff...) are found only in for-profit concerns" (Hulme and Mosley, 1996, pp. 157 and 158).

None of the three arguments, however, is truly convincing. Firstly, the fact that something has not been attempted does not mean that it cannot be done. Secondly, private companies may not be willing to invest venture capital in microfinance, but donors do not expect them to. In downscaling projects, a donor agency typically subsidizes the start-up costs of the microloan department. Thirdly, the authors are 
Institutional options for microfinancing

\begin{tabular}{|c|c|c|c|c|}
\hline & & Non-profit & & For-profit \\
\hline \multirow{4}{*}{$\begin{array}{c}\text { Large institution } \\
\downarrow \\
\downarrow \\
\downarrow \\
\downarrow\end{array}$} & Formal & Public policy bank & & \multirow{4}{*}{$\begin{array}{c}\text { Privately owned bank } \\
\mathbb{\Omega} \\
\mathbb{v} \\
\text { Downscaling }\end{array}$} \\
\hline & Formal FI & \multirow{3}{*}{$\begin{array}{c}\text { Upscaling } \\
\text { 仓े } \\
\text { iे } \\
\text { NGO }\end{array}$} & \multirow[t]{3}{*}{ Greenfield bank } & \\
\hline & serving target group & & & \\
\hline & Semiformal & & & \\
\hline Small & Informal & Church funds & & Private moneylender \\
\hline
\end{tabular}

undoubtedly correct in asserting that private-sector management techniques can be transferred to non-profit organizations. This is precisely the purpose of upscaling an NGO and what led to the success of the marketoriented approach to microfinance. However, an equally or even more successful approach to building MFIs might be to utilize the "natural" incentive of for-profit companies to cover costs, rather than transforming a non-profit institution geared to helping a given target group into an organization that abides by budget constraints and the requirements of economic efficiency.

Nevertheless, Hulme and Mosley's arguments contain the key to understanding the crucial difference in alternative institution-building approaches (table 1). They compare non-profit with for-profit MFIs, rather than upscaling with downscaling. By alluding to an institution's size and to its movement up or down a scale, these expressions, established in the microfinance literature to characterize the two opposing strategies for building MFIs, are, at best, misleading. In institutionbuilding, size is less important than other considerations. The key difference is the ownership and governance structure of the partner institution that is to be transformed into an MFI. In upscaling projects, the typical NGO partner is a small non-profit institution that belongs to the informal or semiformal financial sector. A commercial bank that serves as the partner of a downscaling project is generally a bigger entity that is already registered as a formal financial institution. However, the essential conditions for such a project are the business goals and the ownership structure of the commercial bank: for a "genuine" downscaling project, the institution should be a private-sector forprofit bank. If the institution is a State-owned bank, it will have features similar to those of an $\mathrm{NGO}$, regardless of how large and formal it may be. In contrast, a private moneylender, even if small and informal, shares key characteristics with private commercial banks. Seen in this light, the creation of a greenfield bank is not really an additional option. ${ }^{9}$ In addition to the fact that creating a de novo bank saves the time needed to transform an existing institution, and instead requires the effort of building an institution from the ground up, greenfield banks may have the institutional features of either nonprofits or for-profits, depending on their ownership and governance structure-an issue that needs to be examined (table 1).

What are the main differences in the ownership and governance structure of non-profits and for-profits that determine the distinct challenges of transforming each type of institution into a formal MFI? The most common prejudices as to the essential difficulties faced in institution-building and that prevent an MFI from fulfilling its dual mission might provide the first clues. While a non-profit partner institution would, naturally, set out to serve the target group of the poor, it is commonly assumed that it would encounter difficulties in ensuring efficiency and taking the necessary steps to cover costs. In contrast, a private bank will supposedly strive, on its own account, to ensure costefficiency and profitability. The main problem of institution-building will be to convince the bank to serve the target group of microclients.

These portrayals are certainly oversimplified. To give just one example, albeit an important one: nonprofit MFIs as well as for-profit banks usually have appointed managers, who could (mis-)use such

\footnotetext{
${ }^{9}$ See Baydas, Graham and Valenzuela (1997).
} 
institutions to attain certain personal objectives instead of meeting the needs of the target group or maximizing profits. Therefore, one may not take for granted that non-profits will use funds exclusively for the target group, nor can it be assumed that cost efficiency is the natural attribute of a for-profit bank. Nevertheless, the common prejudices certainly contain some truth. Indeed, the main challenge in the design of the governance structure of a non-profit institution - whether an NGO or a State-owned bank- is the establishment of tight budgetary constraints that prevent it from losing money. The main difficulties in establishing such constraints in non-profit institutions have to do with the structure of ownership and control: if equity is donated to an institution or its ownership structure is diluted, as is typically the case with Stateowned banks, there is no owner with a personal interest in using the rights of control and accountable for the institution's (financial) successes and failures (table 2). Private companies certainly have an advantage in this regard. Not only do their owners have an incentive to multiply their shareholder value by exercising their rights of control, but such companies also face the threat of insolvency if they lose their capital-a risk that also compels appointed managers to be more cautious. Finally, private companies usually face competition, which limits the margin of inefficiency that each individual company can afford. To compensate for their weaknesses in financial sustainability, non-profits may imitate the management techniques of for-profits mentioned by Hulme and Mosley (1996). However, even if the "transplant" of these for-profit techniques into a non-profit is successful - and there are numerous examples to the contrary- ${ }^{10}$ it is a time-consuming and expensive proposition, as the lengthy and protracted process of upscaling NGOs illustrates.

The ownership structure of a for-profit bank therefore undoubtedly has advantages in cost coverage, as a guarantor of the institution's sustainability. The main difficulties lie (and here, again, the most common prejudices against for-profits contain some truth) in achieving target-group orientation. The main barrier is not start-up costs, because donor institutions are willing to subsidize entry costs. It is the long-term business prospects of serving microclients that could make a forprofit institution unsuitable as an MFI.

\footnotetext{
10 The many failed attempts to reform State-owned policy banks should suffice as examples.
}

While a non-profit institution will reach sustainability as soon as it covers its operational and financial costs and avoids decapitalization, neither a microfinance department in a for-profit bank nor a forprofit MFI will break even and become sustainable at the same point. For microfinance to be lucrative and for a for-profit institution to continue providing that service even while donor subsidies are phased out and the accompanying donor controls are removed, not only must it be profitable but it must be just as profitable as any business activity competing for a bank owner's limited resources. This benchmark, which determines the sustainability of microfinance in for-profit banks, has been referred to in microfinance literature as "full financial sustainability". This degree of sustainability includes, among other things, the need to cover the opportunity costs of the owner's equity.

This threshold is unavoidable for a for-profit, but it is irrelevant for the survival of a non-profit institution. A private company that is fully integrated into the market is considered to be driven by the goal of profit maximization and by the forces of competition to put scarce resources to their most efficient use. Non-profit institutions are not bound by these market forces in the same way. They are subject to different rules of survival because by definition they are motivated by factors other than purely financial ones. The simple fact that equity is donated to an NGO frees it from the necessity to cover the opportunity cost of equity. As long as it does not incur losses, it could survive almost forever, even while earning significantly less return on equity (ROE) than a for-profit bank.

Hence, microfinance in a for-profit bank is the touchstone of the microfinance promise: if microfinance can be made a truly profitable business in for-profit banks, there is no need for lifetime subsidization of nonprofit institutions. Even if such subsidies are provided only in the form of donated equity, donor control will always be necessary to prevent them from being misused through organizational slack. ${ }^{11}$

For-profit MFIs do have advantages, if microfinance can, in fact, be made a win-win solution within a limited period of time. We need to ask if the innovations in the institutional set-up of MFIs, namely downscaling and

\footnotetext{
${ }^{11}$ This has been a recurring problem in the history of German savings banks. Two hundred years after their founding as non-profit institutions owned by the states and municipalities, they are still organized as non-profit NGOs.
} 
TABLE 2

The challenges of institution-building:

non-profits versus for-profits

\begin{tabular}{|c|c|c|}
\hline & Non-profits & For-profits \\
\hline Sustainability & "Transplanted" mechanism & "Natural" mechanism \\
\hline Cost coverage & Threat of insolvency if donation flow is cut off & $\begin{array}{l}\text { Risk of insolvency because owners' } \\
\text { funds are limited }\end{array}$ \\
\hline Efficiency & $\begin{array}{l}\text { Prevention of organizational slack through } \\
\text { imitation of for-profit management techniques/ } \\
\text { donor control }\end{array}$ & $\begin{array}{l}\text { For-profit management techniques; } \\
\text { competition; management under or } \\
\text { controlled by owner }\end{array}$ \\
\hline Target-group orientation & $\begin{array}{l}\text { Donor control to prevent managers from } \\
\text { misusing the institution for personal goals }\end{array}$ & $\begin{array}{l}\text { Donor control to prevent owners from } \\
\text { using subsidies for more profitable, } \\
\text { non-target-group business }\end{array}$ \\
\hline \multicolumn{3}{|l|}{ Subsidies } \\
\hline Temporary & $\begin{array}{l}\text { To cover losses until institution is able to cover } \\
\text { costs and maintain equity }\end{array}$ & $\begin{array}{l}\text { To ensure that target-group business } \\
\text { covers costs (including the opportunity } \\
\text { cost of the equity) }\end{array}$ \\
\hline Open-ended & $\begin{array}{l}\text { Equivalent to the return on equity on an } \\
\text { alternative investment }\end{array}$ & \\
\hline Donor control & $\begin{array}{l}\text { For an indefinite period/ until transition to a } \\
\text { for-profit company }\end{array}$ & $\begin{array}{l}\text { Until target-group business is as } \\
\text { profitable as alternative investments }\end{array}$ \\
\hline
\end{tabular}

the founding of greenfield banks, actually imply experimentation with for-profit ownership structures, and if so, if they hold out the potential of making the microfinance promise a reality.

\section{III}

\section{Is downscaling for-profit banks worth trying?}

Downscaling of this type has been tried, and, although some of the partner commercial banks were State-owned, there are cases of true downscaling projects in which partner banks were privately owned and that therefore constitute typical examples of forprofits.

\section{Latin America: downscaling in Paraguay}

One very prominent downscaling project was the Programa Micro Global, which started in 1995 in Paraguay with Inter-American Development Bank (IDB) financing. ${ }^{12}$ Eight partner institutions, of which only

\footnotetext{
${ }^{12}$ See Schor (1997).
} 
one was a State-owned bank, took part in the programme. The rest were privately owned financial institutions (financieras) that had formerly specialized almost exclusively in consumer loans. At all of these institutions a microloan department was established with donor support in the form of technical assistance. Microloan officers were trained to issue individual loans to microentrepreneurs using the customary microloan technology: a careful assessment of clients' payment capacity, the issue of a short-term instalment loan, and close monitoring of payment discipline, followed by longer-term and/or larger loans if the client proved reliable. Furthermore, the donor would offer a credit line, distributed by a second-tier bank, to fund new businesses. This credit line was not, however, issued as a soft loan to the first-tier lending institution. The only advantage of this credit line was the access it afforded to funds with slightly longer maturities than could be found on the financial market.

By late 1996, five institutions had proven particularly active in the new line of business: they had built up portfolios of between US\$ 0.5 and 6 million and issued loans for an average of US\$ 1,300 and with an average maturity of just over one year. Although the State-owned bank was one of these five institutions, two years after the programme began, it already showed remarkable differences $v i s-\grave{a}$-vis the private financieras: the average loan granted was almost double that of the financieras (US\$ 2,120 versus approximately US\$ 1,000), the average maturity was significantly longer (22 versus 12.5 months) and the interest rate was, at $3.3 \%$ per month, lower than that of the private institution charging the lowest rate ( $4.8 \%$ per month) and less than half that of the financiera charging the highest rate $(6.8 \%) .{ }^{13}$ These figures seem to suggest that the State-owned bank was less interested in generating profits than were the other banks, although at that time none of the five had reached the breakeven point. However, the two largest were reported to be approaching profitability.

At the end of the programme, in the spring of 2001 , all four of the active financieras were on the verge of profitability. The two biggest had built up microloan portfolios of between US\$ 8 million and US\$ 12 million, ${ }^{14}$ which represented a significant portion $(25 \%$ and $70 \%)$ of their total portfolio volume

\footnotetext{
${ }^{13}$ Ibid.

${ }^{14}$ See Mommertz (2001, p.8).
}

and generated much $(75 \%$ and $60 \%)$ of their profit. ${ }^{15}$ All these institutions remained in the microfinance business, and for one of them microloans are its most important business line-in fact, its advertising touts it as "the leader in microfinance". 16 The average loan amount remained at US\$ 1,000 over time, which is a clear indicator that these institutions actually serve microclients. Real annual interest rates, on loans in local currency, are as high as $60 \%$ per year-rather high, considering that inflation in Paraguay is below $10 \%$. Nevertheless, these rates are not unusual in the country.

This provides clear proof that microloan departments established in for-profit financial institutions in Latin America can attain full financial sustainability. Consequently, the institutions will remain in this line of business after subsidies for entering the market are phased out. However, the experience in Paraguay might not be representative of all of Latin America. Paraguay is not the only country where downscaling has been tried. Indeed, the Programa Micro Global was implemented in several countries, and Paraguay was clearly one of the most successful cases and is probably the most successful example of true downscaling in Latin America. ${ }^{17}$

\section{Eastern Europe: downscaling in Kazakhstan}

In Eastern Europe, a kind of testing ground for institutional innovations in microfinance, the history of projects aimed at establishing microfinance in private commercial banks is generally much shorter; nevertheless, it can be expected that showcase projects with experiences comparable to those of Paraguay are being developed. The Small Business Programme in Kazakhstan, started in 1998 by the European Bank for Reconstruction and Development (EBRD), may be an outstanding example. ${ }^{18}$ Seven commercial banks either privately owned or privatized by 2001 participated. By late 2002, the banks had built up a microloan portfolio of US\$ 73 million. The average loan amount disbursed is US\$ 5,100 and the average amount outstanding is US $\$ 4,200$. These figures are four to five times higher than in Paraguay. However, the average amount of customary loans for all Eastern European microloan

\footnotetext{
${ }^{15}$ Oral information from the programme consultant.

16 See www.vision.com.py.

${ }^{17}$ For more information, see Wenner and Campos (1998).

${ }^{18}$ Information gathered during a visit to the programme; source of data: www.ipcgmbh.com.
} 
projects is typically higher than it is in Latin America. As of now, not much can be said about the profitability of these microloan departments, as subsidies for institution-building have not been phased out and figures on contribution to profits are not publicly available. Still, in personal interviews, the managers of the participating banks clearly stated their long-term commitment to microfinance because of its favourable business prospects. Furthermore, not only is the largest commercial bank of Kazakhstan, Kazkommertsbank, one of the partner banks but it has also built up one of the largest single microfinance portfolios (US\$ 16.9 million). These are highly reliable indications that microfinance will survive after the donor agencies have ceased to support them.

Nevertheless, in Kazakhstan there are also clear signs that banks do not consider microloans, and especially those for smaller amounts, the most attractive business for allocating their own resources. Firstly, most of the banks are more interested in the medium-sized and large individual loans granted under the Small Business Programme. Some of the banks would even like to see the upper limit for loans granted under the programme raised. The supporting donors, in contrast, have a special interest in ensuring that the programme reaches the smaller microclients. Secondly, staff members trained as loan officers under the Small Business Programm are frequently promoted within the banks to fulfil duties with greater responsibilities. Microfinance seems to be valued because the programme offers training and the transfer of knowhow, which are valuable in and of themselves, even if the microloan business per se is less attractive than are transactions with bigger clients. The drain of human resources will most likely continue until scarce resources used for microfinance can generate the same profitability as those used in other lines of business. This could occur in the near future because Kazakhstan's financial sector is characterized by high competition.
Kazakhstan clearly meets the requirements for becoming a resounding success story for the downscaling approach. However, as with the Latin American case, in Eastern Europe not all downscaling projects have had equally favourable results. After a relatively slow beginning, the programme in the Ukraine seems as promising as the one in Kazakhstan. The programme in Russia, the oldest in Eastern Europe, began in 1994 but was hit hard by the Russian financial crisis, which not only affected the quality of the loan portfolio but also drove several partner banks into insolvency. Only one of the partner banks, which has the legal structure of a corporation whose largest shareholder is the government and therefore cannot be classified as a true for-profit partner, is still operating. Several small projects, such as those in Armenia, Romania and Macedonia, are either too recent to allow a prognosis or are less promising than the Kazakhstan project.

Although the evidence on downscaling provided here comes down to two rather successful cases, some preliminary conclusions on the potential of establishing microfinance departments in for-profit financial institutions can be drawn:

- Successful examples do exist, but they are (still) rare.

- Those examples have the following characteristics:

- The financial market in both countries is very competitive, and existing for-profit institutions are therefore always looking for new business.

- The financial market for microclients is not sufficiently covered by established non-profit institutions, which offer the same product but have the competitive advantage of being precisely that: non-profits.

In sum, microfinance with for-profits is possible, but thus far the successful examples do not indicate that the era of commercial microfinance is under way. ${ }^{19}$

\footnotetext{
${ }^{19}$ Mommertz (2001) and Berger (2000) arrive at similar conclusions.
} 


\section{IV}

\section{Building greenfield banks:}

\section{a compromise between}

\section{for-profit and non-profit}

The sample of greenfield banks surveyed here covers some of the most prominent but certainly not all the greenfield banks that might have been founded around the world. All of the MFIs mentioned here belong to the same "microfinance network", encompassing donor institutions, a microfinance investment company, a consulting firm specializing in development finance and the micro banks themselves. Within this sample, the greenfield bank approach was first applied to Eastern European countries in transition. The first MFI, called Micro Enterprise Bank (MEB), was founded in Bosnia and Herzegovina in 1997, followed soon afterwards by FEFAD Bank, in Albania. Meanwhile the greenfield bank approach has extended to Africa, Latin America and Asia, although with only one or two institutions on these continents. To date, most of the 15 greenfield banks are located in Eastern Europe.

As all these MFIs had a formal banking or financial institution licence from the outset, most of them are already offering, or at least aim to offer, complete banking services. Besides micro- and small-business loans and time and savings deposits, both in local and foreign currencies, these banks offer payment services, and some also issue letters of credit or traveller's cheques. Obviously, these banks do not want their microclients to transfer their transactions to other formal banks once they become small or medium-sized firms. On the contrary: the greenfield banks aim to become established players in the local financial market.

The approach to building these banks was always similar. The banks were legally established as corporations, and the local minimum-equity requirements for founding a bank were met with funds raised from donor agencies.

As shown in table 3, which gives an overview of the ownership structure of the banks under consideration, the donors that appear as shareholders of all of these banks are, in general, the same: the German development bank Kreditanstalt für Wiederaufbau (KfW); International Finance Corporation (IFC), of the World Bank Group; Netherlands
Development Finance Company (FMO); the Dutch foundation DOEN; the European Bank for Reconstruction and Development (EBRD). At the same time, the donor community holds a majority interest in almost all of these banks.

The fact that the donors have a majority holding leads to one important conclusion: although these banks have the legal status of private companies and the governance structure of corporations with appointed managers and a supervisory board, they cannot be considered "truly" private. The legal structure is merely an instrument that donors use to experiment with institutional innovations in development finance.

However, the fact that a majority of the shareholders of these banks are non-profit institutions does not imply that private investors are not at all involved. One of the shareholders is a financial institution that operates solely for profit-Commerzbank, a big German commercial bank. Interestingly enough, this bank has invested exclusively in Eastern European banks, which might indicate that these banks' business prospects make them more attractive for private investors than would investing in a microbank in Ghana or Haiti.

One additional investor appears in all of these banks: IMI AG, a German investment company that specializes in holding equity participation in microbanks. ${ }^{20}$ Most of its investments are in shares of these greenfield banks, although it has also invested in MFIs created via upscaling, such as Caja Los Andes, in Bolivia, or Calpiá, in El Salvador. The legal status of IMI AG is that of a private company, but it is justifiably characterized as a mixture of a for-profit and a nonprofit company. An examination of the shareholder structure of IMI AG reveals a near duplication of that of the microbanks themselves, since its majority interest is held by the same non-profit institutions. The investment company Deutsche Investitions-und

\footnotetext{
${ }^{20}$ See IMI, http://www.imi-ag.de.
} 
Ownership structure of greenfield banks

(Percentages)

\begin{tabular}{|c|c|c|c|c|c|c|c|c|}
\hline & \multicolumn{5}{|c|}{ Development institutions (non-profit) } & \multirow{2}{*}{$\begin{array}{c}\text { Mixed } \\
\text { IMI }\end{array}$} & \multirow{2}{*}{$\begin{array}{c}\text { For-profit } \\
\text { Commerzbank }\end{array}$} & \multirow{2}{*}{$\begin{array}{c}\text { Others } \\
\text { (for-profit or } \\
\text { non-profit) }\end{array}$} \\
\hline & KfW & IFC & FMO & DOEN & EBRD & & & \\
\hline \multicolumn{9}{|l|}{ Eastern Europe } \\
\hline \multicolumn{9}{|l|}{ Micro Enterprise Bank, } \\
\hline Bosnia and Herzegovina & 8 & 23 & 12 & - & 23 & 22 & 12 & \\
\hline Microfinance Bank of Georgia & 20 & 16 & 10 & - & 10 & 29 & 15 & \\
\hline Micro Enterprise Bank, Kosovo & 16 & 16 & 16 & - & 16 & 16 & 16 & \\
\hline FEFAD Bank, Albania & 25 & 20 & - & - & 20 & 15 & 20 & \\
\hline Micro Enterprise Credit, Moldova & - & 15 & - & 15 & 15 & 40 & - & 15 \\
\hline Micro Finance Bank, Serbia & 16 & 16 & 16 & - & 16 & 16 & 16 & \\
\hline Microfinance Bank, Ukraine & 20 & 20 & - & 10 & 20 & 10 & - & 20 \\
\hline ProCredit Bank, Bulgaria & 20 & 20 & - & - & 20 & 20 & 20 & \\
\hline MIRO Bank, Romania & 20 & 20 & 10 & - & 20 & 10 & 20 & \\
\hline \multicolumn{9}{|l|}{ Latin America } \\
\hline Micro Credit National, Haiti & - & 20 & 15 & - & - & 20 & - & 45 \\
\hline Sociedad Financiera Ecuatorial, & & & & & & & & \\
\hline Ecuador & - & - & - & 33 & - & 56 & - & 11 \\
\hline \multicolumn{9}{|l|}{ Rest of world } \\
\hline NovoBanco, Mozambique & - & 13 & 13 & 13 & - & 25 & - & 35 \\
\hline MEB, Philippines & - & 10 & 10 & 20 & - & 20 & - & 40 \\
\hline Sikaman SLC, Ghana & - & 25 & 20 & 20 & - & 32 & - & 3 \\
\hline
\end{tabular}

Source: Internationale Micro Investitionen Aktiengesellschaft (IMI), www.imi-ag.de.

Entwicklungsgesellschaft (DEG), which belongs to the KfW, holds $14 \%$ of the shares; IFC, $16 \%$; DOEN, $16 \%$; FMO, $14.5 \%$; BIO, the Belgian Investment Company for Developing Countries (BIO), another $7 \%$; and ProCredito, a Bolivian foundation involved in microfinance, $6 \%$.

However, there are two purely private investors: IPC GmbH (19.5\%) and IPC Invest (7\%). IPC GmbH specializes in providing consulting services for microfinance; IPC Invest is a vehicle for IPC employees to invest their own savings. This is undoubtedly a very special set of private investors: the investments are made exclusively by private individuals who at the same time receive income from the microfinance consulting business and who, furthermore, are involved in the institution-building process of the microbanks, since their employer, IPC GmbH, is contracted by the donor agencies to provide management services for the microbanks during the initial institution-building phase. These private investors, who through IMI AG hold an indirect equity participation in the greenfield banks, complete the greenfield banks' institutional structure.

The greenfield microbanks as well as the investment company IMI AG have a truly innovative institutional structure:
- Behind the facade of for-profit companies is a mixture of non-profit and for-profit investors-a mixture that with little effort can be fine-tuned in keeping with the business prospects of any local MFI and, in general, of any microfinance. When microfinancing not only covers expenses but also begins to recover the opportunity cost on equity, then the microbank is performing well enough to be truly privatized. At this point, the structure of the shareholders could be changed by donors selling their shares to private investors. Similarly, when investments in MFIs have become truly competitive, donors could exit IMI AG, which could even go public.

- The similarity in the ownership structure of all these greenfield banks ensures information sharing, coordination and thereby the realisation of economies of scale related to control over investments and the accumulation of know-how.

- Furthermore, the fact that the consulting company IPC and its employees hold an indirect interest in the microbanks while simultaneously working, under a management services contract, for them, is a variation of a new incentive model. This model, called "consulting for equity", has recently emerged in Western industrialized countries. The basic idea 
FIGURE 1

\section{Governance structure of the greenfield bank network}

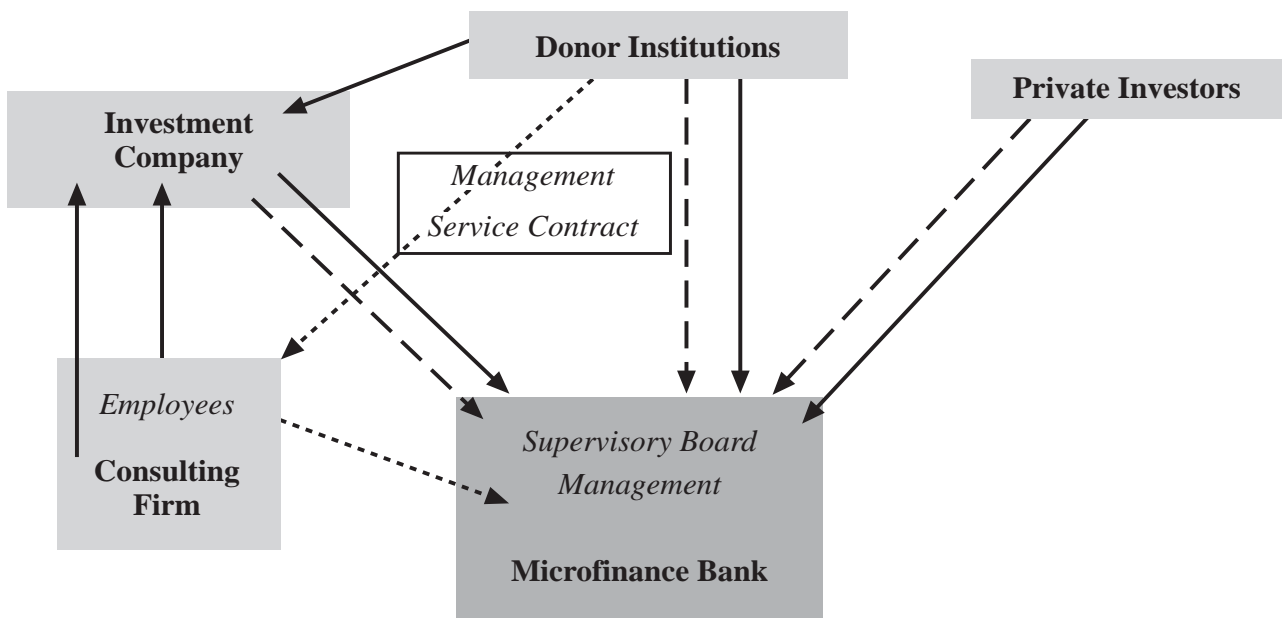

Source: Prepared by the author.

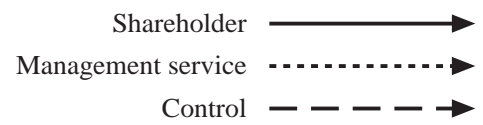

behind it is to give consultants an incentive to act in the interest of the owners of a business that uses their consulting services. If the consulting service is successful, the consultants take part in the success, since the value of their shares rises. Likewise, if the consultants fail to solve problems, their equity holding earns no income.

How well has this institutional network, which was built in the last five years around the founding of greenfield banks, performed?

Concerning outreach ${ }^{21}$ and target-group orientation, the success of the greenfield banks is impressive, as table 4 shows.

In fact, the average amount of the loans in Eastern Europe is significantly higher than that of those extended by, for example, the Latin American institutions. This reflects the different environment in the transition countries as well as, perhaps, a different definition of the target groups of the Eastern European banks, which do not aim to serve the poorest of the poor. All the institutions under consideration show very low rates of arrears (figure 2), which is consistent with a moderate level of write-offs. However, the question

${ }^{21}$ See Gonzalez-Vega (1998). of whether "high repayment rates translated into profit" remains (Morduch, 1999, p. 1571).

Table 5, which examines the return on equity realized by all greenfield banks, may provide a preliminary, although not altogether unbiased, impression.

In their official accounting reports, audited by recognized external auditing firms, the vast majority of MFIs more than two years old report a profit. Naturally, and unfortunately for academics interested in having statistics on the success of this institution-building approach, the official accounting data do not reflect the degree to which an institution still needs subsidies. These institutions may continue to receive subsidies, either in the form of technical assistance paid for by the donors (such payments for managerial services would not even appear on an institution's books) or in the form of soft loans. To get a more realistic picture one would require "shadow" accounting data corrected to include subsidies -data that are not publicly available. However, the following information may give a first insight.

- After two to three years, banks should be able to cover their administrative costs, including management salaries. All banks that had begun operations two or three years before, and even some banks that had been created more recently, met this target. 
TABLE 4

\section{Greenfield banks: Outreach and target-group orientation}

\begin{tabular}{lccc}
\hline December 2002 & $\begin{array}{c}\text { Total amount of loans outstanding } \\
\text { (thousand of euros) }\end{array}$ & $\begin{array}{c}\text { Average amount of } \\
\text { outstanding loans (euros) }\end{array}$ & $\begin{array}{c}\text { Number of loans } \\
\text { outstanding }\end{array}$ \\
\hline MEB, Bosnia and Herzegovina & 33533 & 4513 & 7077 \\
FEFAD, Albania & 29826 & 5227 & 5434 \\
MBG, Georgia & 33098 & 1110 & 29815 \\
MEB, Kosovo & 23731 & 5018 & 4504 \\
MEC, Moldova & 3992 & 3593 & 1111 \\
ProCredit, Bulgaria & 29317 & 5467 & 5107 \\
MFB, Ukraine & 26055 & 4098 & 6056 \\
MFB, Serbia & 40133 & 3844 & 9942 \\
MIRO, Romania & 10104 & 3900 & 2591 \\
MCN, Haiti & 2981 & 881 & 3383 \\
SFE, Ecuador & 6746 & 1293 & 5217 \\
NovoBanco, Mozambique & 1998 & 277 & 7212 \\
MEB, Philippines & 360 & 201 & 1794 \\
Sikaman, Ghana & 282 & 552 & 487 \\
Benchmark institutionsa/ & & & \\
Caja Los Andes, Bolivia & 61272 & 1200 & 51073 \\
Calpiá, El Salvador & 42717 & 954 & 44771 \\
CONFIA, Nicaragua & 15023 & 736 & 20418 \\
\hline
\end{tabular}

Source: IMI AG.

a/ NGOs that had already been upscaled to microbanks.

FIGURE 2

Greenfield banks: Arrears, December 2002

(Percentages)

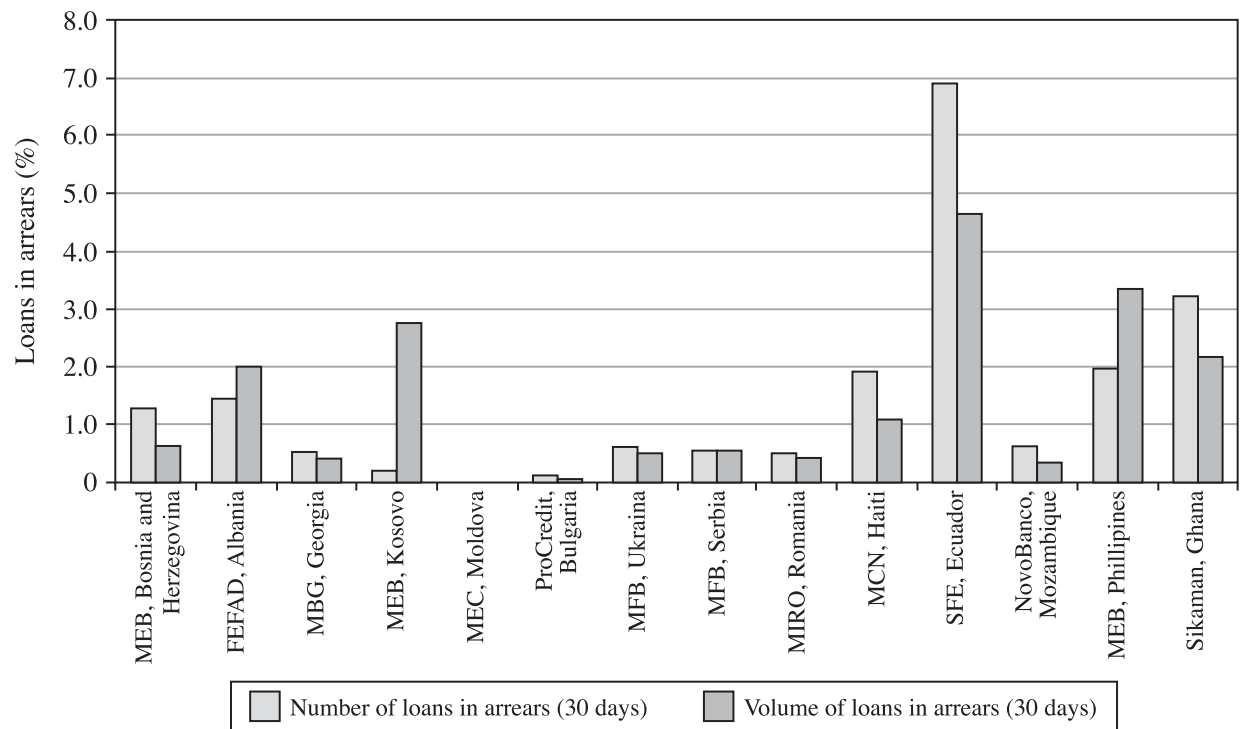

Source: IMI AG. 
TABLE 5

Profitability of greenfield banks throughout the world

\begin{tabular}{|c|c|c|c|c|}
\hline December 2002 & Year founded & $\begin{array}{l}\text { Return } \\
\text { on equity }\end{array}$ & $\begin{array}{c}\text { Equity } \\
\text { (millions of euros) }\end{array}$ & $\begin{array}{c}\text { Profits } \\
\text { (millions of euros) }\end{array}$ \\
\hline \multicolumn{5}{|l|}{ Eastern Europe } \\
\hline \multicolumn{5}{|l|}{ Micro Enterprise Bank, Bosnia and } \\
\hline Herzegovina & 1997 & $8 \%$ & 7 & 0.56 \\
\hline Microfinance Bank of Georgia & 1999 & $-1 \%$ & 11 & -0.11 \\
\hline Micro Enterprise Bank, Kosovo & 1999 & $53 \%$ & 7 & 3.71 \\
\hline FEFAD Bank, Albania & 1999 & $15 \%$ & 7 & 1.05 \\
\hline Micro Enterprise Credit, Moldova & 2000 & $-7 \%$ & 5 & -0.35 \\
\hline Micro Finance Bank, Serbia & 2001 & $-26 \%$ & 14 & -3.64 \\
\hline Microfinance Bank, Ukraine & 2001 & $-1.9 \%$ & 10 & -0.19 \\
\hline ProCredit Bank, Bulgaria & 2001 & $1 \%$ & 7 & 0.07 \\
\hline MIRO Bank, Romania & 2002 & $-9 \%$ & 10 & -0.9 \\
\hline \multicolumn{5}{|l|}{ Latin America } \\
\hline Micro Crédit National, Haiti & 2000 & $27 \%$ & 2 & 0.54 \\
\hline $\begin{array}{l}\text { Sociedad Financiera Ecuatorial, } \\
\text { Ecuador }\end{array}$ & 2001 & $10 \%$ & 3 & 0.3 \\
\hline \multicolumn{5}{|l|}{ Rest of world } \\
\hline NovoBanco, Mozambique & 2000 & $-6 \%$ & 2 & -0.12 \\
\hline Micro Enterprise Bank, Philippines & 2001 & $-11 \%$ & 2 & -0.22 \\
\hline Sikaman SLC, Ghana & 2002 & $-5 \%$ & 2 & -0.1 \\
\hline \multicolumn{5}{|l|}{ Benchmark institutions $^{\mathrm{a} /}$} \\
\hline Financiera Calpiá, El Salvador & 1988 & $11 \%$ & 11 & 1.21 \\
\hline Financiera CONFIA, Nicaragua & 1990 & $18 \%$ & 3 & 0.54 \\
\hline Caja Los Andes, Bolivia & 1992 & $13 \%$ & 10 & 1.3 \\
\hline
\end{tabular}

Source: Internationale Micro Investitionen Aktiengesellschaft (IMI), www.imi-ag.de.

a/ NGOs that had already been upscaled to microbanks.

- To create a greenfield bank from the ground up, including a home office and one or two branches, and for it to attain sustainability, in the sense of covering all expenses, an average of 1.5 to 2 million euros in subsidies is required. Naturally, this amount will depend on the size of the bank.

- Three of the microbanks (FEFAD Bank, of Albania; MEB, of Bosnia and Herzegovina; and MEB Kosovo) no longer receive direct subsidies. Only MEB's results are affected by soft loans.

Two or three of these banks, therefore, appear to be profitable, despite having existed for only a short period. However, the ROE is probably insufficient to cover the opportunity cost of equity that a private investor would calculate, taking the country risk into account. Furthermore, ROE alone is not sufficient for a comparison of the profitability of investments. For a profitability assessment based on net present values, the total cost of investments and the amount that can be invested with a certain average rate of return need to be taken into account. Nevertheless, the data presented suggest that progress has been made in building MFIs, aided by intelligent and innovative ownership and governance structures.

It would be unfair, however, to conclude that these institutional innovations have brought the microfinance promise much closer to realization. The reason for this is given in the following section. 


\section{$\mathrm{V}$}

\section{Conclusion and outlook}

Institutional innovation was characteristic of the "microfinance industry" at the end of the 1990s and at the beginning of the new millennium. The term "microfinance industry" was deliberately chosen because these innovations were, undoubtedly, carried out by the faction of the microfinance movement that believes in microfinance more as an instrument for developing financial markets than as a development tool for directly fighting poverty. For this reason, the duration and degree of subsidization required to achieve financial sustainability are used as the main indicator of success, rather than a cost-benefit measure of the impact on poverty per dollar spent.

If such a cost-benefit measure were applied, institutions that reach much poorer clients and raise their income might possibly receive a more favourable evaluation than the greenfield banks discussed above, even if the former continued to depend on subsidies (Morduch, 1999, pp. 1592-1595). There is little point in carrying out a more in-depth analysis here because - to cite Morduch's seminal paper again"unfortunately, for now policy makers have little to go on beyond a handful of case studies and...theoretical examples and counter examples" (ibid., 1595). In all fairness, it has to be stressed that none of the institutions examined in this paper claim that their mission is to serve the poorest of the poor, even if some members of this segment of the population are among their customers. The concept of for-profit microfinance, as well as the founding of greenfield banks, seeks to develop the financial market by reaching customers who have not yet been served, but in a top-down rather than a bottom-up manner. In the light of this development goal, the time and money invested to achieve financial sustainability seems to be a pragmatic, but acceptable, yardstick.

The use of this yardstick - albeit, due to a lack of information, as a very rough estimate - reveals some noteworthy examples of downscaling as well as of greenfield banks with very satisfactory performance. It cannot be ruled out, however, that most of the success of greenfield banks is attributable to the special economic situation of the transition countries. And, regarding downscaling projects, the very fact that few of them have been successful and that donors support the founding of greenfield banks with mixed ownership, even in some countries where the downscaling approach is simultaneously supported, seems to indicate that the day when microfinance will provide a win-win solution is still far off. And, last but not least, it should be mentioned that the new institutional model of greenfield banks might produce new institutional issues. To name just a few:

- Does the new "consulting for equity" incentive model, meant to bring the interests of consultants in line with those of donors, have the potential to lead to new incentive problems, as well? (Sties, 2003).

- What is the optimal exit point for the donor-owners of greenfield banks? And how is it guaranteed that such an exit will actually be executed?

- Could the founding of greenfield banks with mixed ownership constitute the future barrier to the entry of private banks into the microfinance business, with the adverse effect that institutions meant to develop the financial market would contribute to market distortions?

Much more research is required to give satisfactory answers. 


\section{Bibliography}

Adams, D.W., D.H. Graham and J.D. Von Pischke (1984): Undermining Rural Development with Cheap Credit, Boulder, Colorado, Westview Press.

Banerjee, A. (2002): The Uses of Economic Theory: Against a Purely Positive Interpretation of Theoretical Results, MIT Working paper 02-24, Cambridge, Massachusetts, The MIT Press.

Baydas, M.M., D.H. Graham and L. Valenzuela (1997): Commercial Banks in Microfinance: New Actors in the Microfinance World, Economics and Sociology Occasional Paper, No. 2372, Columbus, Ohio, The Ohio State University.

Berger, M. (2000): Microfinance: An emerging market within the emerging markets, in S. Sawers, D. Schydlowsky and D. Nickerson (eds.), Emerging Financial Markets in the Global Economy, Washington, D.C., American University.

Gonzalez-Vega, C. (1998): Microfinance: Broader Achievements and New Challenges, Economics and Sociology Occasional Paper, No. 2518, Columbus, Ohio, The Ohio State University.

Hulme, D. and P. Mosley (1996): Finance against Poverty, vol. 1, London, Routledge.

(1998): Microenterprise finance: Is there a conflict between growth and poverty alleviation?, World Development, vol. 26, No. 5, Oxford, United Kingdom, Pergamon Press, May.

Khandker, S.R., H.A. Samad and Z.H. Khan (1998): Income and employment effects of micro-credit programmes: village-level evidence from Bangladesh, Journal of Development Studies, vol. 35, No. 2, London, Frank Cass Publishers, December.
Krahnen, J.-P. and R.H. Schmidt (1994): Development Finance as Institution Building, Boulder, Colorado, Westview Press.

Mommertz, R. (2001): Micro Global en Paraguay, Internal Working Paper, Frankfurt, IPC GmbH.

Morduch, J. (1999): The microfinance promise, Journal of Economic Literature, vol. 37, No. 4, Nashville, Tennessee, American Economic Association.

(2000): The microfinance schism, World Development, vol. 28, No. 4, Oxford, United Kingdom, Pergamon Press.

Rhyne, E. H. (2001): Mainstreaming Microfinance: How Lending to the Poor Began, Grew and Came of Age in Bolivia, Bloomfield, Connecticut.

Schor, G. (1997): Commercial Financial Institutions as MicroLending Partners. Some Lessons of the Micro Global Program in Paraguay, IPC Working Paper, Frankfurt.

Sties, A. (2003): Ownership Structure and Corporate Governance: Consulting for Equity in Development Finance Projects, University of Heidelberg, unpublished.

Vogel, R. (1984): The effect of subsidized agricultural credit on income distribution in Costa Rica, in D.W. Adams, D.H. Graham and J.D. Von Pischke, Undermining Rural Development with Cheap Credit, Boulder, Colorado, Westview Press.

Wenner, M. D.and S. Campos (1998): Lecciones en la penetración de la banca comercial en microfinanzas: El caso de Banco de la Empresa, S. A., IDB Working Paper, Washington, D.C., InterAmerican Development Bank (IDB). 